\title{
Compensating victims of a European Deepwater Horizon accident: OPOL revisited
}

Citation for published version (APA):

Faure, M. G., \& Wang, H. (2015). Compensating victims of a European Deepwater Horizon accident: OPOL revisited. Marine Policy, 62, 25-36. https://doi.org/10.1016/j.marpol.2015.08.017

Document status and date:

Published: 01/12/2015

DOI:

10.1016/j.marpol.2015.08.017

Document Version:

Publisher's PDF, also known as Version of record

Document license:

Taverne

Please check the document version of this publication:

- A submitted manuscript is the version of the article upon submission and before peer-review. There can be important differences between the submitted version and the official published version of record.

People interested in the research are advised to contact the author for the final version of the publication, or visit the DOI to the publisher's website.

- The final author version and the galley proof are versions of the publication after peer review.

- The final published version features the final layout of the paper including the volume, issue and page numbers.

Link to publication

\footnotetext{
General rights rights.

- You may freely distribute the URL identifying the publication in the public portal. please follow below link for the End User Agreement:

www.umlib.nl/taverne-license

Take down policy

If you believe that this document breaches copyright please contact us at:

repository@maastrichtuniversity.nl

providing details and we will investigate your claim.
}

Copyright and moral rights for the publications made accessible in the public portal are retained by the authors and/or other copyright owners and it is a condition of accessing publications that users recognise and abide by the legal requirements associated with these

- Users may download and print one copy of any publication from the public portal for the purpose of private study or research.

- You may not further distribute the material or use it for any profit-making activity or commercial gain

If the publication is distributed under the terms of Article $25 \mathrm{fa}$ of the Dutch Copyright Act, indicated by the "Taverne" license above, 


\title{
Compensating victims of a European Deepwater Horizon accident: OPOL revisited ${ }^{\text {is }}$
}

\author{
Michael Faure ${ }^{\mathrm{a}, *}$, Hui Wang ${ }^{\mathrm{b}}$ \\ ${ }^{a}$ Comparative and International Law at Maastricht University and Comparative Private Law and Economics at Erasmus University, Rotterdam, Netherlands \\ ${ }^{\mathrm{b}}$ Maastricht University, Maastricht, Netherlands
}

\section{A R T I C L E I N F O}

\section{Article history:}

Received 26 November 2014

Received in revised form

13 July 2015

Accepted 4 August 2015

Available online 29 August 2015

Keywords:

Deepwater Horizon

Victim compensation

Offshore related incidents

Critical analysis OPOL

Europe

\begin{abstract}
A B S T R A C T
The introduction sketches the importance of the Deepwater Horizon incident that occurred five years ago on 20 April 2010 in the Gulf of Mexico. The question central to this contribution is how compensation would be provided if such an incident were to occur in European waters. A mechanism that plays an important role in Europe, more particularly for the North Sea is the Offshore Pollution Liability Association Limited, referred to as OPOL. Section 2 introduces OPOL by elaborating the origins, main features, membership rules, financial responsibility and claims handling. Section 3 discusses OPOL in the UK regulatory environment which is particularly interesting since OPOL membership in the UK is mandatory. Section 4 provides a critical analysis by first describing the practice of OPOL and next discussing the advantages and limits of this particular scheme. Section 5 discusses which insurance and financial instruments are used in Europe in areas where OPOL does not apply. In turn self-insurance, (re)insurance as well as risk-pooling schemes are discussed. Finally Section 6 examines to what extent it would be possible to expand OPOL either in amount or in geographical scope (more particularly beyond the North Sea). Section 7 concludes.
\end{abstract}

(c) 2015 Elsevier Ltd. All rights reserved.

\section{Introduction}

On 20 April 2010 an explosion occurred on the mobile deepwater offshore rig Deepwater Horizon, located in the Gulf of Mexico to drill the Macondo well. As a result immediately several workers on the platform died and efforts to control the oil and preventing it from leaking into the ocean failed. An amount of 3.19 mio. barrels of oil spilled into the sea with dramatic consequences for the coastal states in the South of the US. ${ }^{1}$ Although at this moment the total amount of the damage in financial terms is still unknown, it is anyway clear that this led to an unprecedented damage and to the highest environmental damage ever that occurred in the US.

This Deepwater Horizon incident led to an important wake-up

This paper builds on a research done for the European Commission $\rangle\langle h t t p: / / e c$. europa.eu/dgs/energy/tenders/doc/2013/20131028_b3-978-1_final_report.pdf). The authors are grateful to the editor and to an anonymous referee for useful comments on an earlier version of this paper.

* Corresponding author.

E-mail addresses: Michael.faure@maastrichtuniversity.nl (M. Faure), appleandhui@yahoo.com (H. Wang).

${ }^{1}$ Judgment of the US District Court for the Eastern District of Louisiana filed on 15 January 2015, in: In re: Oil Spill by the Oil Rig "Deepwater Horizon" in the Gulf of Mexico, on April 20, 2010. call in other parts of the world as well, including in Europe. Whereas in the US the incident was covered by the Oil Pollution Act (OPA) of 1990, European policy-makers rapidly found out that international conventions concerning marine pollution only deal with vessel-source oil pollution. ${ }^{2}$ There are no such conventions dealing with damage that could result from an offshore incident like the Deepwater Horizon in EU waters.

Luckily the Deepwater Horizon accident happened with one of the largest oil companies in the world, BP. Pressured by President Obama BP could put the gigantic amount of US\$ 20 billion on the table which was put into the Gulf Coast Claim Facility (GCCF) administered by Ken Feinberg. ${ }^{3}$ However, the question arises how compensation would have been awarded if a similar incident were to occur in European waters. As already mentioned, there is no international convention providing a specific answer and the applicable liability regime will of course to an important extent depend upon the national legislation that would apply to such a hypothetical incident. The most important question is

\footnotetext{
${ }^{2}$ For example the International Convention on Civil Liability for Oil Pollution Damage, 1969 (also referred to as the CLC 1969) and the International Convention on the Establishment of an International Fund for Compensation for Oil Pollution Damage, 1971 (the Fund Convention 1971), both regularly amended, inter alia in 1992. For a more detailed description see [20].

${ }^{3}$ For a detailed account of the working of the GCCF see [9], 125-183.
} 
undoubtedly whether in Europe compensation would be available to cover large damage resulting from an offshore accident, hypothetically referred to as a European Deepwater Horizon.

It is a question that is high on the policy agenda of the European Commission. As a result the Commission promulgated on 12 June 2013 Directive 2013/30 on safety of offshore oil and gas operations, ${ }^{4}$ also referred to as the Offshore Safety Directive. This Directive holds as a principle that Member States shall review the financial capabilities of an operator applying for a license, including any financial security, to cover liabilities potentially deriving from the offshore oil and gas operations in question. ${ }^{5}$ This Directive holds that Member States shall ensure that the licensing authority does not grant a license unless it is satisfied with evidence from the applicant that the operator has made or will make adequate provisions to cover liabilities potentially deriving from the offshore oil and gas operations. ${ }^{6}$ This hence means that the Offshore Safety Directive imposes upon Member States to verify financial guarantees to be provided by the operator which should cover liabilities potentially deriving from the offshore oil and gas operations. However, the specific way in which those financial guarantees will be assessed by the Member States has not been determined in the Directive.

Obviously the question what type of financial security would be adequate to cover particular liabilities may depend upon a number of features, inter alia the potential damage that could result from such an offshore incident, but also the amount of cover available on insurance and financial markets. In this article, one particular instrument will be reviewed, and this instrument is currently in use in Europe and more particularly in the United Kingdom to guarantee compensation in case of incidents with offshore oil and gas operations. It is the Offshore Pollution Liability Association Ltd., which has created voluntarily a liability compensation scheme, which is referred to as OPOL. This OPOL is interesting, not only because it is the instrument that is currently in place that would be applicable if a large offshore incident were to occur in the North Sea. Moreover, it is interesting since, although OPOL is a voluntary agreement between operators, membership of OPOL has been made mandatory by the regulator inter alia in the UK where it is de facto a condition for obtaining a license. Hence OPOL constitutes an interesting public-private partnership and is de facto the only semi-official mechanism existing today in Europe to cover damage resulting from incidents with offshore oil and gas operations. That is why this contribution will introduce the main features of OPOL and critically analyze the operation of OPOL more particularly in its capacity to provide cover for an incident with offshore oil and gas operations in Europe.

The remainder of this contribution is structured as follows: after this introduction (Section 1) the main features of OPOL will be introduced (Section 2) and the specific role of OPOL in the UK regulatory environment (where membership of OPOL is de facto mandatory) will be explained (Section 3). The practice of OPOL as well as a critical evaluation will be provided (Section 4) and the question will be addressed what other instruments than OPOL play a role today in covering damage resulting from incidents with offshore oil and gas operations in European waters (Section 5). Since OPOL is today de facto limited to the UK the question will be addressed whether there are possibilities to expand OPOL (Section 6) and a few concluding remarks will be formulated (Section 7).

The approach followed in this contribution is that a law and economics method will be used to analyse the incentive effect of OPOL on operators; in addition several interviews have been held

\footnotetext{
${ }^{4}$ OJ L178/66 of 28 June 2013.

${ }^{5}$ Art. 4(2)(c).

6 Art. 4(3).
}

with representatives of OPOL, major insurers and operators in the offshore oil and gas industry, the results of which are equally incorporated here.

\section{Introducing OPOL}

\subsection{Origins of $O P O L$}

The Offshore Pollution Liability Association Limited (the Association) is an oil industry body, which has been set up as a company limited by guarantee, which administers a voluntary strict liability compensation scheme, referred to as OPOL. It originated in the UK and came into effect on the first of May 1975 as an agreement between all UK offshore operators. The original founders of OPOL were a number of, mostly UK based, oil companies. ${ }^{7}$

The reason for creating OPOL was that at the time operators anticipated that there may be a convention or a regulatory duty, which could be imposed. In the end the convention never came, but OPOL lasted. $^{8}$ All this happened in the 1970 s, when people became more and more conscious of the potential risks of pollution caused by increasing oil exploration activities taking place at the seabed off Northwest Europe. Therefore, some countries in the region decided at the end of 1976 to establish a legal regime to cover the damage caused by offshore pollution incidents. ${ }^{9}$ They have drafted a convention and even signed it on 1 May 1977, the Convention of Civil Liability for Oil Pollution Damage resulting from Exploration for and the Exploitation of Seabed Mineral Resources (CLEE). ${ }^{10}$ However, the ratification of the international convention is a lengthy and complicated process. OPOL thus came into effect as an interim measure while waiting for the ratification of the CLEE. In the end, the CLEE could not come into effect and the UK government decided its interests might be better protected through the continuing function of OPOL. OPOL currently has 122 members. ${ }^{11}$

OPOL covers escapes or discharges of oil from offshore facilities of any "designated state" specified in the OPOL agreement. ${ }^{12}$ However, it does exclude offshore facilities located in the Baltic and Mediterranean Seas. Parties to OPOL are "Operators of or intended to be the Operators of Offshore Facilities" used for oil and gas exploration and production. ${ }^{13}$ In the UK, all offshore operators active in exploration and production on the UK continental shelf are parties to the OPOL. ${ }^{14}$

Meanwhile, OPOL has been extended to cover offshore facilities within the jurisdiction of any state that is specified in the agreement. The states currently covered include the coastal states of the European Community, Norway, the Isle of Man and the Faroe

\footnotetext{
7 More particularly: Amoco (UK) Exploration Company; Burmach Oil (North Sea) Limited; BP Petroleum Development Limited; Total Oil Marine Limited; Conoco North Sea Incorporated; Esso Exploration and Production UK Inc.; Gulf Oil Production Company; Hamilton Brothers Oil Company (GB) Limited; Mobil North Sea Limited; Shell UK Limited; Phillips Petroleum Company; Signal Oil and Gas Company Limited; Siebens Oil and Gas (UK) Limited; Texaco North Sea UK Company; North Sea Sun Oil Company Limited; Cluff Oil Limited.

8 Interview with representatives of OPOL on 27 March 2013 in Brussels.

${ }^{9}$ These countries include UK,Germany, Ireland, The Netherlands, Norway and

10 〈http://sedac.ciesin.org/entri/register/reg-092.rrr.html〉.

11 According to the latest annual report of OPOL 2013, The Offshore Pollution Liability Association Limited Report and Financial Statements for the Year Ended 31 December 2013, available at 〈http://www.opol.org.uk/downloads/Report\%20and\% 20Financial\%20Statements\%20-\%20December\%202013.pdf〉.

${ }^{12}$ They are: the UK, Denmark, Germany, France, Ireland, the Netherlands, Norway, the Isle of Man and the Faroe Islands.

${ }^{13}$ See Preamble of Offshore Pollution Liability Agreement, effective as of

$14\langle$ http://www.opol.org.uk/〉.
} Sweden. 1 April 2015. 
Islands (a total of ten). It is de facto, however, only mandatory in the UK, Greenland and the Faroe Islands. ${ }^{15}$ OPOL membership outside of the UK has declined. The reason is that for operators in countries where there is no regulatory duty to be a member of OPOL (like in the UK) there may not be an incentive to be a member. OPOL is therefore rarely used for example in France, Germany or Denmark. ${ }^{16}$

\subsection{Main features}

OPOL is designed to provide a mechanism for the settlement of claims expeditiously and without disputes. ${ }^{17}$ It establishes a duty to compensate pollution damage based on a strict liability rule.

A second feature is that OPOL guarantees that funds are available to meet claims since members of OPOL need to provide proof of financial responsibility.

The overall limit on compensation is US\$ 250 million per incident. In case of insolvency of one of the members or if a member for other reasons fails to meet its obligations, all remaining members to OPOL agree to contribute, in proportion to the number of relevant offshore facilities operated by it on the date of the incident in question, towards payment of claims due from a party that fails to meet its obligations.

In principle, OPOL is hence based on a strict liability of the operator, member of OPOL, for pollution damage and on a maintenance of financial responsibility. OPOL itself is not a compensation fund but only guarantees payment in case the member of OPOL would fail to meet its obligations.

\subsection{Rules-membership}

OPOL is structured in such a way that operators of offshore facilities can become member of OPOL. In the most recent version of the Offshore Pollution Liability Agreement (OPOL Agreement) of 1 April 2015, an operator is defined as:

"a Person which by agreement with other Persons has been authorized to, and does, manage, conduct, and control the operation of an Offshore Facility, subject to the terms and conditions of said agreement, or which manages, conducts and controls the operation of an Offshore Facility in which only it has an interest." 18

The OPOL Agreement is a contract between the parties to the Agreement. The rights and obligations of the parties in relation to the OPOL guarantee are specifically laid down in the founding documents applicable to the Offshore Pollution Liability Association Ltd., namely the Memorandum of Association and the Articles of Association and in the Agreement. Hence, an operator is both a member of OPOL, the Company as well as a party to the OPOL Agreement. ${ }^{19}$ The key of OPOL is that it obliges its members on the basis of agreement to pay compensation for remedial measures and pollution costs on a strict liability basis. ${ }^{20}$

Clause II.B of OPOL Agreement makes clear that any person which is or intends to be the operator of an offshore facility may become a party upon acceptance by the Association of an application from said person in form prescribed by the Association. De facto this means that the operator who wishes to join OPOL has to

\footnotetext{
${ }^{15}$ Interview with representatives of OPOL on 27 March 2013 in Brussels.

16 Ibidem.

17 Preamble of Offshore Pollution Liability Agreement (OPOL),effective as of 1 April 2015.

${ }^{18}$ Clause I.10 of OPOL Agreement, effective as of 1 April 2015.

19 Interview with representatives of OPOL on 27 March 2013 in Brussels.

${ }^{20}$ Ibidem.
}

file form A from the website of OPOL, being the application to become a party to OPOL and a member of the Offshore Pollution Liability Association Limited. By applying for membership, the member agrees to abide by its memorandum and articles of Association and its rules.

In addition to the OPOL Agreement, an Offshore Pollution Liability Association has also been created which has as main goal to administer OPOL. Operators hence become members both of OPOL as well as of the Association. Clause III.2 specifies that the Association administers any sums which the Association receives from the parties in the event that the party fails to satisfy its obligations to claimants.

\subsection{Financial responsibility}

In the UK, financial capacity and membership of OPOL is made a precondition for a license to be granted for an offshore operator. It is further reinforced by the inclusion of a standard OPOL Clause in all joint operating agreements. The operator must establish and maintain its financial capability to meet claims that arise under OPOL by producing evidence of insurance, self-insurance or other satisfactory measures, with the financial responsibility to meet such capability allocated contractually between the operator and non-operators under a joint operating agreement. ${ }^{21}$

A key element of OPOL is that every party to OPOL agrees under Clause II.C.1 to establish and maintain its financial responsibility to fulfill its obligations under Clause IV of OPOL Agreement with respect to offshore facilities of which it is the operator in accordance with criteria prescribed by the rules.

According to Clause IV, if discharge of oil occurs from one or more offshore facilities the party who was the operator of that offshore facility shall reimburse the costs of remedial measures and pay compensation for pollution damage up to an overall maximum of US\$250 million. Of this US\$250 million, US\$ 125 million per incident shall be reimbursed for the costs of remedial measures incurred by the public authority; another sum of US\$ 125 million per incident shall be available to pay compensation for pollution damage to claimants. ${ }^{22}$

To cover these obligations the operator has to comply with the rules for establishment of financial responsibility. ${ }^{23}$ The operator may use different ways of proving financial responsibility:

1. Insurance, by having an insurance company, agent or broker, which is acceptable to the Association, complete a form referred to as FR1 or FR2 which provides evidence of insurance;

2. A guarantee on form FR3 issued by a guarantor acceptable to the association;

3. A qualification as a self-insurer, by providing a financial statement meeting certain specified criteria. ${ }^{24}$ In order to qualify as a self-insurer, the operator must have one or more of the credit or financial strength ratings from an internationally recognized credit rating agency, such as Standard \& Poor's (A- or higher), A. M. Best (A- or higher), Moody's (A3 or higher), and Fitch (A or higher).

The idea of OPOL is hence that it requires from each operator which is a party to OPOL that it provides satisfactory evidence of its ability to meet any liability under OPOL. Whether this is satisfactory will be verified by the association. OPOL itself makes

\footnotetext{
${ }^{21}$ Offshore Pollution Liability Limited, Offshore Pollution Liability Association Limited Rules, 〈http:opol.org.uk/rules-2.htm〉.

22 Clause IV.A of OPOL Agreement

${ }^{23}$ Form B of OPOL, Rules for establishment of Financial Responsibility.

24 All these forms are available at the website of OPOL, 〈http://www.opol.org. uk/forms.htm>.
} 
clear in its information for prospective members that evidence of financial responsibility is necessary as a protection to the party and claimants to ensure that the party has made adequate provision to meet the obligations assumed under OPOL. In addition, it protects the other parties since they have also agreed jointly to contribute to the payment of claims due from an operator that fails to meet its obligations. This makes clear that operators have a strong incentive to control and monitor the financial guarantees provided by other operators since they could otherwise be liable in case an operator, member of OPOL, would fail to meet its obligations.

\subsection{Claims handling}

OPOL basically covers "pollution damage" and "remedial measures" which will be further analyzed in Section 3.3.

Claimants, either public authorities or individual victims, should file a claim with the operator. Clause V of OPOL Agreement makes clear that the claimant shall "furnish the party against whom a claim has been filed with such information, documents and testimony as are reasonably required by said party in connection with the investigation of the claim and permit the making of such visual or other inspections or surveys as the party may request".

Clause VI of OPOL makes clear that the claim has to be filed within one year from the date of the incident which resulted in the pollution damage or the taking of the remedial measures in question.

According to clause VII any payment to a claimant by or on behalf of a party shall be in full settlement of all said claims against that party and against any other persons associated with that party in connection with the offshore facility or facilities involved with respect to the pollution damage or the costs of remedial measures.

The claim is hence made directly against the operator. Clause V III.C clearly states that the association shall have no liability to any claimant other than its obligation to administer claims in the event that a party fails to satisfy its obligations to claimants.

In that case, each party is obliged to make a payment to the association of the parties' share. The share to be borne by each party is in proportion to the number of units operated by that party to the total number of units of all parties, except that of the defaulting party, at the time of the incident. The brochure of OPOL for prospective members holds: "Thus the amount involved is likely to be only a small proportion of the total sum involved in any claim". 25

In addition, parties have an obligation to pay administration costs for the functioning of the association.

\subsection{Enforcement}

Once a claim has been filed with an operator, only the operator remains responsible for the acceptance and payment of such claims. Payment to a claimant is required to be in full and final settlement of the claim against the operator. However, since OPOL is merely a private agreement between operators OPOL can of course not exclude the possibility that a claimant would not use OPOL but rather file a law suit in ordinary courts.

However, in the event of a dispute between the claimant and the operator as to the application or interpretation of the agreement, either the claimant or the operator can submit the matter to arbitration in London. ${ }^{26}$ According to the OPOL Agreement, arbitration

${ }^{25}$ Available at the website of OPOL, 〈http://www.opol.org.uk/downloads/ opol-memberinfo-jan13.pdf).

${ }^{26}$ Clause IX of OPOL. shall be the exclusive means of disposing of disputes. Arbitrators are bound by the provisions of OPOL and do not have the power or authority to vary or increase the provisions of the contract or any rights or obligations there under. This hence means that arbitrators could e.g. not increase the amounts provided for in OPOL.

In principle, claimants can direct themselves to the operator who will in principle, given the strict liability formula in OPOL, compensate. In case of dispute, however, arbitration in London is the only remedy for the claimant. English law will apply according to clause XII. Clause XIII moreover holds that no person has any right under the Contracts Act 1999 to enforce any term of this contract, but this clause shall not affect any third party rights which might exist apart from that Act.

This clause seems to imply that e.g. victims suffering pollution damage could not execute a direct right of action different than as provided in OPOL before ordinary courts and still call on OPOL. This clause probably has as a goal to exclude victims as third party beneficiaries.

\section{OPOL in the UK regulatory environment}

\subsection{OPOL membership mandatory}

In the UK, the exploration for and production of oil and gas can only be undertaken in accordance with the conditions of a petroleum license issued by the government. ${ }^{27}$ In order to obtain the license, the applicants must demonstrate that they have funds available to meet liability for oil spills in the course of licensed activities. ${ }^{28}$ The Department of Energy and Climate Change (DECC), as the competent licensing authority, requires all operators to have signed up to OPOL.

So far, all offshore operators active in exploration and production on the UK continental shelf are party to the OPOL. ${ }^{29}$ To be a member of OPOL is a pre-condition for a license for the UK offshore operators. There is no obligation to take out financial security under statutory laws, but effectively it is implemented through the practice of DECC in the licensing process: prior to consenting to any exploration or appraisal drilling operations, DECC requires the operator of the offshore facility to be a member of OPOL.

\subsection{Recent developments}

After witnessing the catastrophic scale of damage caused by the Deepwater Horizon incident, concerns were also raised if such an incident happened in the UK. The US\$ 250 million guarantee provided through OPOL might not be sufficient. ${ }^{30}$ Various studies were carried out by the industry, regulators and experts. ${ }^{31}$

Following all these studies and reviews, DECC published in

\footnotetext{
${ }^{27}$ The Petroleum Act 1998 provides in the model clauses that all licensees shall take "all steps practicable" to prevent the escape of oil in the licensed area and the licensees are required to have sufficient funds available to discharge any liability that they may accrue for damage in connection with any oil pollution. For a further discussion on the petroleum license in the UK, see [8], 19-21; [10].

${ }^{28}$ In the UK, with respect to petroleum licenses, several regulations may be relevant since they set out model clauses with related provisions concerning the financial capability of the licensee to discharge any liability that they may accrue for damage in connection with any oil pollution. These regulations may include, Petroleum Licensing (Exploration and Production) (Seaward and Landward Areas) Regulations 2004, the Petroleum Licensing (Production) (Seaward Areas) Regulations 2008, Offshore Exploration (Petroleum, and Gas Storage and Unloading) (Model Clauses) Regulations 2009.

$29\langle$ http://www.opol.org.uk/〉.

${ }^{30}$ In this respect, a UK House of Commons report in December 2010 suggested the amount under OPOL would not be sufficient to cover the costs of a blowout in the UK continental shelf. See [22], 24-26. In this respect, it is interesting to notice that a study by the UK oil and gas industry found that OPOL should be sufficient to meet liability for "all but a few wells". See UK Oil Spill Prevention and Response Advisory Group (2011), 33.

${ }^{31}$ For an overview of some of the major studies, see [18], 570-574.
} 
November 2012 the "Guidance Note to UK Offshore Oil and Gas Operators on the Demonstration of Financial Responsibility before Consent May Be Granted for Exploration and Appraisal Wells on the UKCS" (DECC Guidance Note). ${ }^{32}$ This document outlines DECC's expectations for demonstrating that "the risks of the operation have been appropriately estimated and that the financial mechanisms are in place to meet those risks, should they materialize". ${ }^{33}$

According to the DECC Guidance Note, the largest part of the cost of bringing an exploration or appraisal well under control is the cost of drilling a relief well, which is not covered by the guarantee of OPOL. ${ }^{34}$ The DECC Guidance Note therefore specifies that the level of financial responsibility should cover two aspects of costs: costs of well control and cost of financial remediation and compensation from pollution. ${ }^{35}$ With the DECC Guidance Note coming into effect on 1 January 2013, the evidence of financial responsibility in the licensing process shall also capture drilling operations where the cost of pollution damage and remedial measures exceeds US\$250 million. Such operations have to be topped up to the financial level identified through the accepted industry assessment process to cover the potential damage that may have to be undertaken for that particular operation.

In June 2013, Directive 2013/30/EU was adopted concerning the safety of offshore operations. ${ }^{36}$ This Directive requires that operators shall be able to demonstrate sufficient "financial capabilities, including any financial security, to cover liabilities potentially deriving from the offshore oil and gas operations in question including liability for potential economic damages where such liability is provided for by national law". ${ }^{37}$ As Directive 2013/ $30 / E U$ shall be implemented into national laws by 19 July 2015 , some relevant legislations in the UK have been amended in order to reflect the requirements in the Directive. ${ }^{38}$ It is possible that with the Directive transposed into national law, the financial guarantee as required by OPOL will be granted an explicit legal basis.

\subsection{Basis of liability}

An offshore incident can lead to various damages including physical and economic, personal and environmental. The compensation for these different types of damages may vary and hence the liability for an offshore incident may consist of various layers as well. The liability for offshore incidents in the UK can be threefold:

a. Liability based on OPOL: strict liability;

b. Liability based on statute and model clauses;

c. Liability based on tort.

\footnotetext{
32 The DECC Guidance Note has become effective as of 1 January 2013.

33 DECC, Guidance Note to UK Offshore Oil and Gas Operators on the Demonstration of Financial Responsibility before Consent May Be Granted for Exploration and Appraisal Wells on the UKCS, 2012.

34 Oil \& Gas UK, Guidelines to Assist Licensees in Demonstrating Financial Responsibility to DECC for the Consent of Exploration \& Appraisal Wells in the UKCS, Issue 1, November 2012, 8 .

35 Ibid.

36 Directive 2013/30/EU of the European Parliament and of the Council of 12 June 2013 on Safety of Offshore Oil and Gas Operations and Amending Directive 2004/35/EC, Official J. Eur. Union L 178 (June) (2013) pp. 66-101.

37 Article 4.2 (c) of Directive 2013/30/EU.

${ }^{38}$ E.g. the Offshore Installations (Offshore Safety Directive) (Safety Case etc.) Regulations 2015 (SI 2015/398), the Merchant Shipping (Oil Pollution Preparedness, Response and Co-operation Convention) (Amendment) Regulations 2015, the Environmental Damage (Prevention and Remediation) (England) Regulations 2015 (SI 2015/810), and the Offshore Petroleum Licensing (Offshore Safety Directive) Regulations 2015 (SI 2015/385).
}

First, under the OPOL regime, the liable parties are operators of the offshore facilities, and the liability is strict for pollution damage and cost of remedial measures. The exemptions of liability apply when the incident is caused by following reasons:

a. act of war or force majeure;

b. wholly caused by an act or omission done with intent to cause damage by a third party;

c. wholly caused by the negligence or other wrongful act of government authority, or resulted from compliance with conditions imposed or instructions given by the government; or

d. resulted wholly or partially, either from an act or omission done with intent to cause damage by a claimant, or from the negligence of that claimant. In such a case, the operator shall be exonerated wholly or partially from his obligations to the claimant. $^{39}$ This is known as a comparative negligence defense.

Second, when it comes to statutory liability, there is a substantial amount of legislation in the UK that may relate to offshore oil and gas operations. ${ }^{40}$ This legislation covers the whole process of offshore oil and gas activities from the application for licenses to the construction, operation and eventually decommissioning of a facility, and may concern various aspects of damages such as environmental issue (including prevention of pollution, emergency repose and remediation), and health and safety issue. Therefore, the statutory regime is criticized to be a complex patchwork of disparate provisions. ${ }^{41}$

However, the statutory regime and liability based on tort may still be relevant when it comes to compensation for damage caused by a pollution incident related to offshore activities, especially when the damage is not covered by the OPOL regime. This may concern, inter alia, fatality and personal injury. When liability is based on statutes and common law of tort, the basis of liability may in some cases be strict and in others a claimant may have to establish fault. ${ }^{42}$

\subsection{Compensable damage under $O P O L$}

Under OPOL, the operator of an offshore facility is primarily responsible for payment of the costs of remedial measures and pollution damage. In addition, the parties to the OPOL Agreement have agreed that in the event a party fails to satisfy its obligations to claimants under the Agreement the parties will contribute sums to enable those claims to be met. This is referred to as the OPOL Guarantee. Contributions by the remaining parties would be proportionate to the number of offshore facilities operated by the parties. ${ }^{43}$ To this extent, offshore operators in the UK take part in a scheme which would provide compensation for certain environmental and economic consequences of an offshore oil spill. ${ }^{44}$

The claims to be covered through OPOL concern two categories, "Pollution Damage" and "Remedial Measures".

"Pollution Damage" to be compensated by OPOL is defined as "direct loss or damage (other than loss of or damage to any Offshore Facility involved) by contamination which results from a

\footnotetext{
${ }^{39}$ Clause IV. B of OPOL Agreement.

40 For an overview of the legislation, see e.g. the website of DECC on the licensing and environmental aspects of offshore activities, 〈https://www.gov.uk/ oil-and-gas $\rangle$, and the website of HSE for health and safety aspects of offshore activities, 〈http://www.hse.gov.uk/offshore/law.htm〉.

41 [11], 10; [12], 121

42 For a further discussion on the statutory and tort liability, see [2], 457-475.

43 OPOL website: 〈http://www.opol.org.uk/about-2.htm〉.

44 [23], 5, 76, 153 .
} 
Discharge of Oil". ${ }^{45}$ Therefore, only "direct" damage is covered under the OPOL. According to Clause IV.A of OPOL Agreement, any person (public or private) who sustains pollution damage as defined by OPOL may claim for compensation for pollution damage.

"Remedial Measures" are "reasonable measures taken by any Party from any of whose Offshore Facilities a Discharge of Oil occurs, and of which such Party is the Operator, and by any Public Authority to prevent, mitigate or eliminate Pollution Damage following such Discharge of Oil or to remove or neutralize the Oil involved in such discharge, excluding however, well control measures and measures taken to protect, repair or replace any such Offshore Facility." ${ }^{46}$ The OPOL Agreement provides further in Clause IV.A that only the operator of the involved offshore facility and the public authority taking remedial measures are entitled compensation for their remedial measures. ${ }^{47}$ Therefore, there may be a chance when a private party (other than the operator) took remedial measures, he may not be able to claim reimbursement for his costs in taking remedial measures.

Further clarification on these admissible claims can be found in the OPOL Claimant Guidelines. The Guidelines classify the claims admissible under OPOL into several categories:

1. clean-up operations on shore or at sea,

2. property damage,

3. disposal costs of collected material, and

4. other losses which must be quantifiable and which must result directly from the contamination itself. ${ }^{48}$

Another criterion in the Guidelines provides that claims must be "reasonable, quantifiable and justifiable". ${ }^{49}$ But no further explanation can be found as to the specific meaning of these terms.

Given the rather brief and general definition of "Pollution Damage" and "Remedial Measures", difficulties may arise in practice when it comes to the question whether a specific claim would be compensable under the OPOL regime. First concerning the meaning of "direct loss or damage", it shall be determined by applying English law. Those laws provide that each case will be considered on its merits. However, it remains uncertain as one cannot find an established case referring to "direct" damage, neither does it seem to correspond to the concept of "normal loss", which was distinguished from "consequential loss" as identified in the McGregor case. ${ }^{50}$ It may seem prima facie that personal injury does not fall under the scope of OPOL. Since the damage compensable under OPOL must be "direct", it is yet debatable whether economic losses as a result of an offshore pollution incident are compensable. The question may also arise if damage to the environment itself shall be considered as such a "direct" damage. ${ }^{51}$ Therefore, the definition of "direct damage" under OPOL was criticized for being unclear. ${ }^{52}$

In this respect, it might be interesting to examine the definition of pollution damage in the international regime for oil pollution caused by tankers. This regime is mainly established through two

\footnotetext{
${ }^{45}$ Clause $\mathrm{I} .13$ of OPOL Agreement.

46 Clause I.15 of OPOL Agreement.

47 The OPOL Guidelines for Claimants confirm that as far as remedial measures are concerned, only "Governments, public bodies or authorities (municipal, local or otherwise) may claim in respect of reasonable remedial measures taken by them to prevent, mitigate or eliminate pollution damage or to remove or neutralize oil following an escape or discharge."

${ }^{48}$ Guidelines for Claimants, OPOL. Available at the website of OPOL: 〈http:// www.opol.org.uk/guidelines.htm〉.

49 Ibid.

50 [12], 129

51 Similar concern was raised e.g. in a report by the [22], available at the official website of the UK Parliament: 〈http:publications.parliament.uk/pa/cm201011/ cmselect/cmenergy/450/45007.htm〉.

52 Ibid, 26.
}

international conventions, the International Convention on Civil Liability for Oil Pollution Damage 1992 (Civil Liability Convention) and the International Convention on the Establishment of an International Fund for Compensation for Oil Pollution 1992 (Fund Convention). ${ }^{53}$ These conventions define pollution damage as "loss or damage caused outside the ship by contamination resulting from the escape or discharge of oil from the ship", 54 and "includes the costs of preventive measures and further loss or damage caused by preventive measures". ${ }^{55}$ The definition also specifically mentions "compensation for impairment of the environment other than loss of profit from such impairment shall be limited to costs of reasonable measures of reinstatement actually undertaken or to be undertaken". 56

Through years of experience in handling a large amount of cases, the Fund (established under the Fund Convention) has been developing and updating documents to clarify the definition. The most recent version of such a document is the Claims Manual of October 2013. It addresses specifically the following types of damage:

1. clean-up and preventive measures: compensable if the costs of these measures are "reasonable", wherever these measures are taken, either on the high seas or within the territorial sea of a state that is not a party to the convention. Expenses for preventive measures are recoverable even if no oil spill occurs (pure threat removal), provided that there was a grave and imminent threat of pollution damage.

2. property damage: compensable for reasonable costs of cleaning, repairing or replacing property that has been damaged.

3. consequential loss: this refers to the loss of earnings suffered by the owners of property contaminated by oil as a result of spill. The consequential loss is compensable.

4. pure economic loss: this refers to loss of earnings suffered by persons whose property has not been polluted. Pure economic loss is compensable only under certain circumstances. Moreover, the Claims Manual specifically addresses the use of economic models. It is acceptable only when based on actual data closely related to the loss claimed and with sufficient documentary evidence.

5. environmental damage: compensation for environmental damage is limited to "the costs of reasonable reinstatement measures aimed at accelerating natural recovery of environmental damage". In addition, the Claims Manual stresses that claims for environmental damage based on an abstract quantification calculated in accordance with theoretical models are not admissible to the Fund, nor is compensation paid for punitive damages.

The definition of pollution damage in the international regime for ship-source oil pollution compensation may not be flawless, but it has the advantage of functioning for almost 40 years (since the entry into force of the original conventions in 1975) and the Fund has been working to improve the situation through revision of its Claims Manual to avoid confusion.

Another example of definition of pollution damage is provided

\footnotetext{
${ }^{53}$ These two conventions were originally adopted in 1969 and 1971 respectively, but the current regime is principally governed through the 1992 versions with subsequent revisions. In addition, there is also a supplementary fund to provide on top of these two convention a third layer of compensation. This supplementary funding is adopted through a Protocol of 2003 to the International Convention on the Establishment of an International Fund for Compensation for Oil Pollution Damage 1992. For an overview of these international conventions, see [21], 69-187.

54 Article I.6 of the Civil Liability Convention.

55 Article I.6 of the Civil Liability Convention.

${ }^{56}$ Article I.6 of the Civil Liability Convention.
} 
by the US Oil Pollution Act (OPA) which defines compensable damage as "removal costs" and "damages". ${ }^{57}$ The removal costs include not only the costs incurred by the government, but also those incurred by any person, as long as their acts are consistent with the National Contingency Plan. In this respect, any private party taking preventive/remedial measures who is not covered by OPOL will be entitled compensation under OPA. The "damage" in OPA is defined to include damages to natural resources, real or personal property, subsistence use, revenues, profits and earning capacity, and public services. ${ }^{58}$

Compared to the international regime on ship-source oil pollution and the US OPA, the OPOL definition on pollution damage may seem obscure and too simplified. However, it has not been challenged so far since there is never a case handled under the OPOL in the UK yet.

\subsection{Claims settlement}

The goal of OPOL is said to facilitate rapid payment, since it does not need a lengthy legal action. ${ }^{59}$

Clause VI of the OPOL Agreement (1 April 2015) provides that: "No Party shall have any obligation under this Contract with respect to any Claim filed over one year from the date of the Incident which resulted in the Pollution Damage or the taking of the Remedial Measures in question." Hence, the liability of the operators under the OPOL Agreement will cease unless the claim is submitted within one year since the time the cause of action arises.

In the event of a dispute arising between a claimant and an operator as a party to OPOL, it shall be settled under the rules of arbitration of the International Chamber of Commerce by one or more arbitrators. ${ }^{60}$ Arbitration is generally considered faster and speedier than litigation. ${ }^{61}$ The compensation mechanism of OPOL is designed to provide a quick settlement of claims without the expense of court proceedings. ${ }^{62}$ However, this arbitration clause is only applicable to the parties to the OPOL contract. In the event of a third party victim, the arbitration option may not always be available. $^{63}$

The OPOL arrangement may indeed be faster, compared to litigation in court. The scheme calls on the claimant to notify an operator as soon as possible after an oil spill incident that damage has been suffered and/or costs incurred. OPOL states the scheme is intended to ensure that all claims associated with an oil spill are settled in an orderly and quick manner. However, it does not have a mechanism that would provide immediate compensation to the victims. The mutual guarantee under OPOL is to assure the capability of paying sums due to claimants under OPOL. However, OPOL is not a fund.

\section{Analysis}

\subsection{Practice}

OPOL publishes yearly reports on its website. The most recent report is for the year that ended 31 December 2013. These annual reports, which are relatively brief, merely provide financial statements which largely relate to the administrative costs of operating

\footnotetext{
57 [2], 57-65.

58 33.U.S.C. $\$ 2702$ (b) (2).

59 See OPOL website. OPOL is discussed in further detail in Section 4.1 below.

60 Clause IX of OPOL Agreement, effective as of 1 April 2015.

61 [5].

62 [16].

${ }^{63}$ For a detailed discussion on the arbitration clause in OPOL, see [12], 127-
}

the association.

Importantly, the reports systematically mention "no incident requiring the operation of clause III.2 of the agreement occurred during the year". ${ }^{64}$ This means that until now never a default of the operator took place as a result of which the guarantee clause in the OPOL agreement would come into effect.

De facto in OPOL no member currently relies on selfinsurance. ${ }^{65}$ Of approximately 80 companies in the UK who have provided OPOL with details of financial responsibility currently in place four companies use a company guarantee and hence rely on credit rating of the guarantor. All but four members of OPOL show financial responsibility for operations in the UK via insurance. ${ }^{66}$

The essence of OPOL is that the operator, member of OPOL agrees to settle a claim quickly on a strict liability basis. ${ }^{67}$ The claim has to be filed within 12 months and the operator needs to pay expeditiously. As long as there is no default of an operator OPOL does not intervene in claim settlement. ${ }^{68}$ Hence in the normal cases OPOL has no reason to intervene and the operator will settle the claim. However, the strict liability rule always applies, also if there is no default of an operator. Representatives of OPOL hold that this will guarantee a rapid payment by those who have provided financial guarantee under the OPOL arrangement. ${ }^{69}$ The strict liability to which OPOL members agree guarantees that there will be payment. Hence, normally there should be no problem with a rapid compensation of victims. ${ }^{70}$

As such the OPOL Agreement does not provide a direct right of action to a victim. However, if a victim would be dissatisfied with the way in which one of the OPOL members has handled the claim the victim has the possibility to call on arbitration under the rules of the International Chamber of Commerce.

\subsection{Evaluation}

OPOL has, just on the basis of a preliminary analysis, based on a review of the available documents, undoubtedly many strengths:

1. It provides, as OPOL mentions itself, a strict liability obligation of operators to compensate pollution damage. Clause IV.A makes clear that in case of discharge of oil from an offshore facility the operator "shall reimburse" the costs. Claimants hence do not need to provide proof of negligence or fault.

2. Since claims must be filed against the operator who has caused the pollution, making the operator solely responsible for meeting these claims, a kind of channeling of liability to the operator has taken place. For the claimant, this may have the major advantage that no discussion takes place on attribution of liability.

3. The members of OPOL moreover agree to pay up to a total amount of US\$250 million, which seems substantial.

4. The fact that a strict liability for pollution damage is incorporated in OPOL does not exclude the claimants' right to still sue e.g. for other heads damage (like e.g. personal injury or other types of losses not covered under OPOL). OPOL of course cannot limit the victims' rights on compensation as awarded by law and does not do so.

\footnotetext{
${ }^{64}$ E.g. The Offshore Pollution Liability Association Limited Report and Financial Statements for the Year Ended 31 December 2013, 2.

${ }^{65}$ Interview with representatives of OPOL on 27 March 2013 in Brussels.

66 Ibidem.

67 Interview with Niall Scott, Managing Director of OPOL and Collin Wannell, Chairman of the Board of OPOL on 27 March 2013.

68 Although Ms. Wendy Kennedy, representative of DECC held that OPOL will verify that the members comply with the strict liability duties under OPOL.

${ }^{69}$ Interview with Niall Scott, Managing Director of OPOL and Collin Wannell, Chairman of the Board of OPOL on 27 March 2013.

${ }^{70}$ Interview with representatives of Oil \& Gas UK in London on 1 May 2013.
} 
5. Another strength of OPOL is undoubtedly also the financial guarantee, albeit that question can of course be asked with respect to the strength of the various guarantees required by OPOL.

6. Finally, a strength of OPOL is the element of mutual risk sharing as far as the insolvency of one of the members would be. This is hence important since it guarantees that the obligations mentioned above under OPOL will be met via a proportional obligation to intervene in case of failure of one of the members.

Notwithstanding these strengths and advantages, at first blush also a few limits could be mentioned:

1. The role of OPOL is in a sense relatively limited. OPOL is not, as it also stresses itself, a compensation fund. It merely is an agreement between operators to compensate losses and to provide financial security. Its role is therefore relatively limited.

2. The coverage is limited to pollution damage defined as direct loss or damage by contamination resulting from a discharge of oil. This would mean that e.g. property damage and clean-up operations would be compensated. However, other heads of damage like e.g. personal injury or economic losses are not covered.

Moreover, the coverage of OPOL does not include some major costs, such as the costs of drilling a relief well. The fact that DECC has required financial proof above the OPOL limit shows that the guarantee provided through OPOL in certain cases may indeed by insufficient.

3. The guarantee to provide coverage is merely based on a private agreement between operators. Only in the UK is the obligation to be a member of OPOL also a condition for obtaining a license. However, for EU member states where this is not the case, the voluntary character of OPOL would hence entail that there is no guarantee that financial coverage is available.

4. Although the amount of compensation of US\$250 million seems quite substantial, recent cases like the Deepwater Horizon seem to indicate that in some cases even those limits could be broken.

5. The structure of OPOL is such that usual advantages of a pooling arrangement like risk distribution and mutual monitoring will not be attained. OPOL is indeed not a risk sharing scheme. Risk sharing and risk distribution takes place via the financial security that the operator has opted for like e.g. insurance or other types of security. The guarantee provided by the other operators via clause III (2) is merely to intervene in the event that the party fails to satisfy its obligations. This means that OPOL does not provide incentives for mutual monitoring of preventive measures, but merely for monitoring of the solvency of the other members, which is obviously relatively limited.

6. Questions can also be asked about the importance of OPOL in practice. On the one hand, one could argue that its importance is relatively limited since the guarantee has never been applied in practice and in that sense claimants never had to call on OPOL. However, one could also hold that OPOL has worked well in the sense that apparently the financial guarantee to which OPOL members agree has been able to satisfy all claims without a need to call on the guarantee provided via clause III (2).

7. The application of OPOL is limited to damage resulting from offshore facilities within the North Sea. Offshore facilities located in the Baltic and the Mediterranean Seas are hence explicitly excluded. ${ }^{71}$ Hence, OPOL can only play a role for damage occurring in the North Sea, whereas there are substantial offshore installations in other European waters as well.

\footnotetext{
${ }^{71}$ Interview with representatives of OPOL on 27 March 2013 in Brussels.
}

8. OPOL relies on the information provided by the members to them about the level of financial responsibility which the operator has agreed with DECC. It is according to OPOL, up to DECC to verify the level of financial responsibility required of an operator in relation to each well "OPOL does not track financial viability but it is part of the job of DECC to check this". ${ }^{72}$ If for example the financial responsibility (in case of insolvency) of an operator would reduce, the regulator should recognize this, so OPOL holds. ${ }^{73}$ OPOL waits for information in that respect, provided by operators. This will then be forwarded to the regulator. ${ }^{74}$ This hence means that even as far as the (limited) pooling aspect is concerned (solvency guarantee) OPOL itself does not exercise any active control on the solvency, but relies on the regulator and operators.

9. A final potential limit of OPOL is that it does not at all intervene in case of an incident as long as there is no insolvency. Since there has never been a default of the operator OPOL has no experience and does not intervene in claims handling. ${ }^{75}$

\section{Beyond OPOL}

As has just been shown, if an incident with an offshore oil or gas platform were to take place in an area where OPOL applies (basically the North Sea) the OPOL guarantee would apply up to US $\$ 250$ million. However, as was made clear above, OPOL as such does not provide cover, but merely a promise of compensation in case of insolvency of one of its members. But those members will in turn have to choose different instruments (like self-insurance, insurance or guarantees) to provide cover. Hence, it may be indicated to briefly discuss which insurance and financial instruments are used in Europe in areas where OPOL does not apply. The following discussion will address the use of self-insurance (Section 5.1), (re)insurance (Section 5.2), risk pooling schemes (Section 5.3) and a combination of different instruments (Section 5.4).

\subsection{Self-insurance}

Stakeholders report that especially major oil and gas companies largely use self-insurance and captives to hedge offshore-related risks. This is obviously not only the case for liability following a major offshore accident but also, for the first party damage (like well control costs).

During interviews all majors ${ }^{76}$ confirmed that they use selfinsurance. The argument that is often advanced by the majors is that for them it would make little sense to shift their risks to insurance companies which would force them to pay high costs with little added value as far as financial security is concerned. This is especially the case with some majors that have very high credit rating (for example A minus or higher). A major with such a credit rating would obviously not take insurance coverage with an insurance company that has a lower rating. That would only lead to additional costs and have no added value. However, the number of insurance companies which is rated as high as the major oil and gas companies is relatively limited. That also explains why the majors largely call on self-insurance. ${ }^{77} \mathrm{~A}$ second point is that stakeholders also mentioned that insurance for them is a relatively

${ }^{72}$ Ibidem.
73 Ibidem.
74 Ibidem.
${ }^{75}$ Ibidem.
${ }^{76}$ More particularly Shell, BP and ExxonMobil with whom interviews were
conducted.
${ }^{77}$ It was a point strongly made by representatives of BP during an interview on
13 March 2013.


costly alternative to hedge risks. BP for example refers to a loss experience of $30 \%$. This effectively means that for every 100 dollars $\mathrm{BP}$ would pay in insurance premiums it would also receive 30 dollars back in compensation for losses; the remainder would either go to transaction costs or profits to the insurance company. Because majors consider insurance relatively costly they prefer self-insurance. However, it was equally reported that self-insurance obviously only is a solution for the majors and not for potentially smaller or middle-sized enterprises.

Majors in some cases also make use of captives. For example BP created a captive Jupiter Insurance Ltd. The captive has no staff but is managed by Willis, a large insurance broker. The captive is $100 \%$ owned by BP. In its underwriting policy BP is assisted by AIG who consults the captive on insurance practice, but carries no risk. Legally the captive is an insurance company which can hence underwrite risks.

The reason for creating the captive is that some countries (like in the case of BP Angola) require operators to take out insurance coverage. That explains why the captive is formally set up as an insurer and why the captive also formally underwrites risks, fixes premiums and policy conditions. Some captives do have reinsurance; Jupiter (of BP) not.

BP's captive was inter alia involved in compensating the losses due to the Macondo incident but up to a limit of US\$ 700 million:

1. it paid out US\$300 million, the limit in pollution costs;

2. US\$ 400 million was provided for well control costs, but this amount did not have to be used completely.

The capacity of a captive is of course not unlimited, but limited to the assets brought into the captive by the operator, who owns the shares of the company. In the case of Jupiter a capacity can be provided of US\$ 1,5 billion.

The captive functions completely as a commercial insurance company. That means that also commercial rate premiums are asked, that deductibles are required and that risk dependent premiums are charged as well in order to provide incentives for prevention. Risks are also hedged on the basis of particular underwriting guidelines. The captive hence only differs from an ordinary insurance company through its ownership (owned by a major oil company).

Hence most large companies do self-insurance, but the forms of self-insurance can differ. Some may simply constitute reserves; others could create captives and still others may use the capital market. However, generally for major oil and gas companies the insurance market would not be used. ${ }^{78}$ It was, moreover, also mentioned that in some cases also operators that do use insurance (smaller or medium-size operators) may still use self-insurance to cover a first layer. The first layer would be a so-called retention and insurance coverage would only be asked for higher amounts that the particular operator cannot carry itself. ${ }^{79}$ Larger players in some cases would use for example 400 million euros in self-insurance retention (SIR). But even smaller to medium-size companies could take amounts like 5-10 million in SIR. Also representatives of (re)insurance companies argued that the use of self-insurance may (at least partially via retentions) even be increasing. One reason is the more limited capacity available in the market after Deepwater Horizon. A second reason is due to the mentioned fact that (re)insurance requires higher premiums. ${ }^{80}$ It is important to stress that almost all insurance solutions will

\footnotetext{
78 Interview with the organisation of Oil and Gas Producers (OGP) in Brussels on 25 February 2013.

79 Ibid.

${ }^{80}$ Interview with representatives of Swiss ReInsurance Company on 11 February 2013.
}

include a retention (or deductible). There will normally never be a so-called first dollar coverage for the simple reason that it would be too expensive. ${ }^{81}$

Finally it should also be mentioned that many pointed at the fact that oil and gas companies de facto have a large reserve (of oil and gas) which they have on their balance sheet, but which can de facto also constitute an important reserve to guarantee payment in case of future losses. ${ }^{82}$

\section{2. (Re)insurance}

Insurance is another instrument broadly used to spread the risks related to offshore activities and to provide guarantee for compensation. ${ }^{83}$ By aggregating and spreading risks among the large number of participants, the utility of risk averse individuals can be improved. ${ }^{84}$ Though insurance has the risk to cause moral hazard ${ }^{85}$ and adverse selection, ${ }^{86}$ the experienced insurers can control these problems through mechanisms such as risk differentiation and retention. ${ }^{87}$

Offshore oil and gas activities involve many parties (e.g. operator or licensee, the service company, contractors and equipment providers), and it is common that each party takes insurance to cover their potential risks. ${ }^{88}$ The risks involved in offshore activities represent risks of low probability and large scale of damage once it materializes. Therefore, insurance companies tend to syndicate themselves in order to cover the risks of exposure. The main syndicates are in the London and Bermuda insurance market. ${ }^{89}$

Basically, offshore insurance mainly covers property damage (first party insurance) and liability exposure (third party insurance) ${ }^{90}$ In practice it is common that one single policy is used to cover these two aspects with one single limit. ${ }^{91}$ Many actors provide insurance coverage to offshore facilities. This mainly involves the casualty insurance market, the specific offshore insurance market covering platforms, and the marine insurance (usually covering tankers, but in some cases also offshore and even onshore installations). ${ }^{92}$

A typical offshore insurance may cover the following:

1. Offshore physical damage coverage: it indemnifies the insured for all risks associated with physical loss or damage to fixed offshore drilling, production and accommodation facilities.

2. Operators' extra expense (OEE): this is a policy offered to oil and gas companies that provides coverage for expenses associated to regaining control of a well. This policy typically covers the cost to control operations (both materials used and cost of hiring firms to help control), redrill the well to a depth it was previously, and the cost associated with removing or cleaning

${ }^{81}$ Ibid. This was also mentioned in an interview with Mr. Phil Bell of RSA in an interview on 26 February 2013.

${ }^{82}$ This was especially mentioned by representatives of OGP.

83 [13], 926.

84 See [17], 190.

85 Moral hazard means that the insured's motive to prevent losses changes after he obtained coverage, since the risk of paying a large amount of damages is removed from him. See [19], 95.

${ }^{86}$ Adverse selection refers to the fact that "the tendency of persons with relatively greater exposure to risk to seek insurance protection."[15], 1521, 1541.

87 [6], 321; [1], 942, 949.

88 [7], 41

89 [14].

90 First party insuranice refers to the insurance that individuals take to protect themselves against the future losses that they may suffer themselves, either in their income or in their property, e.g. a fire insurance; third party insurance refers to the insurance taken for the risk that one has to compensate damage suffered by a third party, e.g. a liability insurnace.

91 For further discussion, see [3], 15-16; [4], 106.

92 Interview with Swiss Re, 11 February 2013. 
seepage/pollution. ${ }^{93}$ The policy can also be extended to cover expenses associated with the property of others in the insured's care, underground blowout, evacuation expenses, removal of wreck, and legal expenses emanating from the incident. ${ }^{94}$

3. Environmental/pollution liability: it provides coverage for bodily injury, property damage, and cleanup costs as a result of pollution incident.

4. Business interruption/ loss of production income: it provides coverage for energy businesses against loss due to temporary interruption in oil and gas supply from an offshore facility.

5. Comprehensive general liability: provides coverage for claims an energy business is legally obligated to pay as a result of bodily injury or property damage to a third party.

6. Workers compensation/employers liability: provides coverage for claims arising out of employee injuries or deaths incurred while employee is in the line of duty. ${ }^{95}$

Several studies illustrate that due to lack of information and publicly available data, it is difficult to make accurate estimates of the capacity of the insurance market for offshore risks. ${ }^{96}$ Nevertheless, interviews with insurance experts and offshore operators point at the direction of approximately US\$ 500 million to US\$ 1.5 billion to be available for third party insurance in the market. ${ }^{97}$ However, insurers believe that the capacity for offshore related risk is volatile. Hence there is not always one billion coverage available in the market and the insurance availability is often decided on a yearly basis. ${ }^{98}$

\subsection{Risk pooling schemes}

There exist in addition to the traditional insurance companies that provide coverage for offshore activities, also mutual insurance arrangements that pool the offshore risks. Two of the most known mutual insurers are Oil Insurance Ltd. (OIL) and Oil Casualty Insurance Ltd. (OCIL).

OIL was formed in 1972 by 16 energy companies in response to two large industry accidents that occurred in the 1960s. ${ }^{99}$ OIL is owned and operated for its shareholders, all of whom are engaged in energy operations. It provides coverage for physical damage, costs of well control and third party liability. ${ }^{100}$ The third party liability coverage includes "legal liability (including punitive damages) or contractual liability of members for personal injury, loss of or damage to property arising from a seepage, pollution or contamination incident" ${ }^{101}$ The limit of third party liability coverage is US\$ 300 million. ${ }^{102}$ The operators also need to indicate a deductible in their coverage under the OIL, which should be not less than US\$ 10 million. 103

\footnotetext{
93 International Risk Management Institute (IRMI) provides a definition of OEE insurance, which states that OEE insurance is a "specialized policy available to oil or gas well operators that covers the cost of regaining control of a wild well. Coverage for pollution, stuck drill stem, evacuation expense, and care, custody, or control (CCC) exposures can be added by endorsement". See the website of IRMI: 〈http:// www.irmi.com/online/insruance-glossary/terms/operators-extra-expense-oee. aspx>.

$94[4], 106$.

$95[3]$.

$96[4]$.

97 [4], 106. Interview with Swiss Re, 11 February 2013; Interview with Phil Bell on 26 February 2013.

${ }^{98}$ Interview with representatives of Lloyds on 1 May 2013 in London.

99 The well blow out off the coast of Santa Barbara in Southern California in 1969, and a refinery explosion in 1967 in Lake Charles in Louisiana. 〈http:oil.bm/ about-oil/at-a-glance $\rangle$.

$100\langle$ https://www.oil.bm/products/all-risk-physical-damage〉.

101 〈https://www.oil.bm/products/3rd-party-pollution-liability

102 Id.

103 OIL, Premium Indication Request Form, available at: 〈https://www.oil.bm/ images/stories/Forms/PIRF\%20-\%20May\%202013.pdf).
}

OCIL was founded in 1986 "as an insurance provider owned by companies in the energy industry to pool similar risks". ${ }^{104}$ The goal of such an institute was to "limit exposure to the often volatile commercial insurance and reinsurance market". ${ }^{105}$ It provides excess general liability insurance and is exclusively dedicated to servicing energy companies. OCIL was created in 1986 "at a time when the commercial markets had ceased to provide adequate insurance coverage for liability risks". ${ }^{106}$ OCIL was created by the members of OIL who recognized the need to create a special industry-owned vehicle, specializing in liability insurance. For OCIL it is not necessary to become a shareholder; energy companies could also simply become a policy holder without being a shareholder of OCIL. ${ }^{107}$

Some of the majors are not very enthusiastic concerning risk pooling in OIL and OCIL. The reason is that are opposed to the mutuality inherent in a risk-sharing scheme. ${ }^{108}$ They argued that their loss experience is better than the average risk and in that case negative redistribution would arise since they contribute to the higher risks posed by other members. OIL in fact does not function as insurance with risk dependent premium.

Particular major oil companies argue that the standard rates charged by OIL and OCIL do not sufficiently reflect differing risks. ${ }^{109}$ They argue that risk differentiation is better with insurance companies. The current pools mutualize (based on solidarity) but premiums do not sufficiently reflect risk and hence do not reward the good risks. For that reason the pools are in fact only attractive for middle size companies: since the majors usually pose better risks they do not find the pools attractive and do not need the pools. For the smaller companies the high deductibles (of 10 million USD) do not make membership attractive. That is why only medium size players will join. ${ }^{110}$ Representatives from insurers also hold that in case of a large claim OIL will try to recoup some of the money they had to pay to the third party. Via retrospective premiums part of the money would have to be paid back, which makes such a model less attractive. ${ }^{111}$

Moreover, operators also argue that the risk pools do not have a full solidarity since, depending upon the contractual arrangements, in some cases the liable operator will be compensated by OIL or OCIL but will have to repay (a part of) the damage over a specific (usually five years) period. ${ }^{112}$ Also other majors held that OIL and OCIL are not attractive for major players. The mutualisation in OIL and OCIL could lead to the danger for major players of smaller operators free riding on the majors in which case the majors would de facto become the guarantors of small players. ${ }^{113}$ They argue that currently within these pools the risk differentiation is too low.

The problem is that damage can be potentially very high, but the probability of an accident is very low. Hence, given low probabilities, the difference between e.g. a good risk and a high risk may be that the good risks pays e.g. US\$ 30,000 in contribution and a high risk US\$ 60,000. The difference is not large enough to provide adequate incentives for prevention. The high risk

\footnotetext{
${ }^{104}$ OCIL Casualty Insurance Ltd. Annual Report 2011, at 6. Available at: 〈http:/ www.ocil.bm/images/PDFs/OCIL\%202011\%20ANNUAL\%20REPORT\%20ELECTRONIC\% 20VERSION.pdf $\rangle$.$$
105 \text { Id. }
$$$$
106 \text { 〈http://www.netlinkbermuda.com/Articles/OIL.html〉. }
$$$$
107 \text { 〈http://www.ocil.bm/about.html〉. }
$$$$
108 \text { Interview with representatives of BP on } 26 \text { March } 2013
$$$$
109 \text { Interview with representatives of BP on } 26 \text { March } 2013 .
$$$$
110 \text { Ibid. }
$$

111 So representatives of Lloyds, interview on 1 May 2013 in London. They argue that these pools were created at a moment when there was less cover available in the market, but that they may be less needed today.

112 Discussion with representatives of OGP on 25 February 2013.

113 Interview with representatives of Shell International BV.on 14 March 2013 in Rotterdam.
} 
operator could simply pay the contribution and still free ride on good risks that have to contribute after an accident. Pools hence provide for smaller players with limited balance sheets some kind of safety net and risk differentiation is simply not sufficient. ${ }^{114}$

In sum, OIL and OCIL are apparently attractive for some middle size players. However, for smaller players they may not be attractive (given large retention) and for major players they may not be attractive either given the danger of a negative redistribution (low risk majors contributing to high risk members in the pool, thus creating adverse selection).

\subsection{Combinations}

In practice it is rare that only one type of instrument would be used. In fact this may only be the case for the majors who effectively only use self-insurance or captives. Others de facto often use a combination of different hedging strategies whereby, logically, the comparative benefits of the various instruments are used for an optimal combination. The combination of various instruments may have the advantage of spreading the risk among various players and increasing the available capacity. ${ }^{115}$

As an example: a middle sized operator may choose a retention (self-insurance) of for example 5 million and choose insurance or a risk pooling scheme to cover the excess risk. Moreover, he could (and in the case of the UK must) also be a member of OPOL in which case he would use the self-insurance and insurance in combination as proof of financial security.

The type of combinations that will be chosen by operators in practice may of course to an important extent depend upon their size, and hence their assets but also the type of risks to which they are exposed on the one hand and on the other hand the relative costs of various strategies to transfer risk like the relative costs of insurance versus risk pooling.

Summarizing, the following instruments are currently used to cover liability following a major offshore accident:

1. Self-insurance, largely by the majors, who in some cases create captives as well.

2. The capital market, although actually today only to a very limited extent.

3. Guarantees are possible in theory, but not that often used in practice. Bank guarantees or letters of credit are simply considered too costly and hence not used.

4. (Re)insurance is undoubtedly the most often used mechanism of financial security for offshore related risks.

5. Risk pooling schemes like OIL and OCIL are mostly used by middle-size players.

6. OPOL is not as such a system of financial security, but OPOL is important in the UK where membership of OPOL is mandatory for offshore operators in order to obtain a license.

7. In practice, depending upon their size, balance sheet, assets and risks to which they are exposed, operators may use a combination of any of the financial instruments mentioned above.

\section{Expanding OPOL}

From the analysis above it became clear that the OPOL mechanism is an interesting example of a public-private partnership that can guarantee compensation to victims of accidents resulting from offshore oil and gas operations, at least within the current OPOL limits. However, as one of the limits of OPOL the relatively

\footnotetext{
114 Ibid.

115 [2], 128.
}

limited scope of OPOL was mentioned. Hence the question arises whether there are possibilities to expand OPOL either in amount or in geographical scope. Theoretically there are undoubtedly various possibilities to enlarge the scope of OPOL:

1. One possibility would be to make OPOL membership mandatory in more legal systems. That would hence mean that the OPOL solvency guarantee would expand and e.g. also extend to Norway, Denmark or the Netherlands. ${ }^{116}$ Ultimately, this would obviously be something for the local regulators to decide and is beyond the decision of OPOL. Still, one would have to take into account the limits of OPOL: since it is not a true risk sharing agreement, it only provides a solvency guarantee and moreover only up to US\$ 250 million which is only for the smallest incidents.

2. A second possibility is to expand the amount of coverage of OPOL. That would e.g. mean that the current solvency guarantee would be increased from US\$250 million to, say, US\$ 500 million. Again, the majors are opposed to such a proposal for the same reason as they would not like to join risk pools like OIL or OCIL: it increases the mutualization and hence increases the risk which they would not desire. ${ }^{117}$ Also representatives of OGP were not strongly in favor of increasing the current limit on OPOL. ${ }^{118}$

3. A third possibility would be to expand the scope of the current OPOL beyond the North Sea (to which its application is currently limited). Not surprisingly, many are opposed against such an idea for the same reasons as why they do not want to increase the amount: increasing the current OPOL to an EU wide model, e.g. including the Mediterranean or the Black Sea, would mean that for the current members (who may not at all be active in the Mediterranean) risks would increase, whereas the members may not have sufficient possibilities to monitor the solvency of operators in those other areas. For that reason, they would be opposed against such a territorial expansion. ${ }^{119}$ Industry is opposed against making OPOL multinational since it could lead to one country having to pay for the risk created by other countries. ${ }^{120}$

4. A fourth possibility is that different regional agreements, like OPOL, would be created, e.g. for the Baltic, the Black Sea and the Mediterranean. In that case, there would be no risk sharing (as far as insolvency is concerned) between the operators active in the current OPOL (in the North Sea) and e.g. operators active in the Mediterranean. A new OPOL would then be created specifically e.g. for Mediterranean risks. That is a model that all stakeholders seem to subscribe to for the simple reason that the risks of mutualization and cross-subsidization are then limited. Moreover, mutual monitoring (of the insolvency risk) is easier when new regional risk pools would be created.

5. A fifth possibility would be to transform OPOL altogether from the current model (whereby it merely guarantees the solvency of its members) to a truly risk sharing agreement like OIL and OCIL. Again, it may not surprise that for the same reasons why the majors did not want to join OIL and OCIL they would also not be in favour of such a transformation of OPOL from merely guaranteeing the solvency of its members to a true risk sharing agreement. Again, the fear for mutualization and cross-

\footnotetext{
116 Where OPOL membership is currently not mandatory.

117 Interview with representatives of BP, 26 March 2013; interview with representatives of Shell International BV, 26 March 2013.

118 Discussion with OGP on 25 February 2013.

119 Interview with representatives of BP, 26 March 2013; interview with representatives of Shell International BV, 26 March 2013. This was also confirmed in an interview with representatives of OPOL on 27 March 2013 in Brussels.

120 So representatives of Oil \& Gas UK, interview on 1 May 2013 in London.
} 
subsidization would inhibit such a model.

It should be added that also some operators point at the limits of OPOL in its current form: it is currently only mandatory in the UK and the amount is too limited. Moreover, the mere fact that OPOL never had to intervene could (wrongly according to some regulators) be interpreted as proof of the fact that it functioned well and that there hence would be no risk for the future. Even with the current OPOL, there is a serious risk that there may be some players that could not meet their obligations in the future. ${ }^{121}$ Moreover, contributions to OPOL are not risk-related and hence once more good risks pay for the bad risks as a result of which a negative redistribution takes place. Since OPOL also only intervenes when the operator would default OPOL in its current form lacks the benefits of mutual monitoring of risk-sharing schemes. ${ }^{122}$

In sum, the only option to expand OPOL which was positively received by stakeholders, was the fourth option mentioned above, i.e. to create other regional risk pools for other sea areas than the North Sea along the lines of OPOL: a pooling agreement where members share the insolvency risk of their members. Still, it would have to be recalled that this (1) does not have benefits of mutual monitoring; (2) would only provide limited amounts of coverage and (3) would only intervene to guarantee solvency up to the limited OPOL amounts. Still other arrangements would have to be developed to cover for medium and large accidents.

\section{Concluding remarks}

Compensation for damage caused by offshore installations has been in the core of the media and academic attention since the Deepwater Horizon incident happened in the spring of 2010. This contribution examined the way in which such an incident would be compensated if it were to happen in European waters and more particularly in the North Sea. It was shown that there is an industry arrangement, OPOL, although regulators, more particularly in the UK, also rely on OPOL to provide a guarantee that operators will be able to compensate the damage caused by an offshore related incident. Offshore has been able to function adequately in the sense that its guarantee (in case of noncompliance of one of its members) never had to be used. One unavoidable limit of OPOL is, however, that its territorial scope is limited to the North Sea and that the cover only amounts to US\$ 250 million. However, the example of OPOL shows that it may be interesting, also for regulators, not to immediately seek to impose a regulatory duty on operators e.g. to have compulsory insurance in place, but rather to rely on industry initiatives like OPOL which show also a lot of flexibility in meeting the goals that the regulator wishes to achieve: having compensation available at the moment that a major offshore installation is happening. Hence, it may, also in future initiatives at a EU level, in further implementation of the Offshore Safety Directive of 12 June 2013, be interesting how OPOL could constitute an interesting example for other waters (like the Mediterranean, Baltic or the North Sea) and how OPOL could potentially be expanded as well.

\section{References}

[1] K. Abraham, Environmental liability and the limits of insurance, Columbia Law Rev. 88 (1988) 942-988.

[2] BIO by Deloitte, Civil Liability, Financial Security and Compensation Claims for Offshore Oil and Gas Activities in the European Economic Area, Final Report Prepared for European Commission - DG Energy, 2014.

[3] Booz Allen Hamilton, The Offshore Oil and Gas Industry Report on Insurance, 2010. Available at 〈http://www.eoearth.org/files/172301_172400/172373/in surance_report_part-one_oct_5_4-pm_r1.pdf $\rangle$.

[4] S. Bosma, The regulation of marine pollution arising from offshore oil and gas facilities: an evaluation of the adequacy of current regulatory regimes and the responsibility of states to implement a new liability regime, Aust. N. Z. Marit. Law J. 26 (2012) 89-117.

[5] A. Budiman, On Liability for Offshore Oil Spillage: Strictly Settled, 2009. See 〈http://www.ibanet.org/Document/Default.aspx?DocumentUidentified〉.

[6] K. Crocker, A. Snow, The efficient effects of categorical discrimination in the insurance industry, J. Political Econ. 94 (1986) 321-344.

[7] C. Emmerson, Arctic Opening: Opportunity and Risk in the High North, Lloyd's and Chatham House, London, 2012.

[8] J. Easo, Managing the risk of catatrophic events on the UK continental shelf, Ashurst Energy Source 7 (2010) 19-22.

[9] K.R. Feinberg, Who Gets What? Fair Compensation after Tragedy and Financial Upheaval, Public Affairs, New York, 2012.

[10] G. Gordon, J. Paterson, E. Usenmez, Oil and Gas Law- Current Practice and Emergeing Trends, 2nd edition, Dundee University Press, Dundee, 2011.

[11] G. Gordon, Oil, water and law don't mix: environmental liability for offshore oil and gas operations in the UK, Environ. Law Manag. 25 (2013) 3-11.

[12] G. Gordon, Oil, water and law don't mix: environmental liability for offshore oil and gas operations in the UK, part 2 regulatory law, the environmental liability directive and OPOL, Environ. Law Management 25 (2013) 121-132.

[13] R. Hartwig, C. Wilkinson, An Overview of the Alternative Risk Transfer MarketHandbook of International Insurance, Huebner International Series on Risk, Insurance and Economic Security Vol. 26 (2007) 925-952.

[14] R. King, Deepwater Horizon Oil Spill Disaster Risk, Recovery, and Insurance Implications, Congressional Research Service, 2010, p. R41320.

[15] G. Priest, The current insurance crisis and modern tort law, Yale Law J. 96 (1987) 1521-1590.

[16] N. Scott, Offshore Industry Compensation Regime, speech at Interspill Conference and Exhibition, London, 2012. Available at: 〈http://www.interspill.org/ previous-events/2012/14-March/pdfs/Offshore\%20Forum\%20Panel\%20-\% 20UK\%20Regime/Niall-Scott-OPOL-Offshore-Industry-Compensation-Regime. pdf $\rangle$.

[17] S. Shavell, Economic Analysis of Accident Law, Harvard University Press, Cambridge, 1987.

[18] A. Wawryk, Research handbook on international energy law, in: K. Talus (Ed.), Research Handbook on International Energy Law, Edward Elgar, UK, 2014, pp. 548-592.

[19] G. Wagner, (Un)insurability and the choice between market insurance and public compensation systems, in: W. Van Boom, M. Faure (Eds.), Shifts in Compensation Between Private and Public Systems, Springer, Vienna, 2007, pp. 87-112.

[20] H. Wang, Shifts in governance in the international regime of marine oil pollution compensation: a legal history perspective, in: M. Faure, A. Verheij (Eds.), Shifts in Compensation for Environmental Damage, Springer, Vienna, 2007, pp. 197-241.

[21] H. Wang, Civil Liability for Marine Oil Pollution Damage: A Comparative and Economic Study of the International, US and Chinese Compensation Regime, Kluwer Law International, Alphen aan den Rijn, 2011.

[22] UK House of Commons, Energy and Climate Change Committee, UK Deepwater Drilling - Implications of the Gulf of Mexico Oil Spill, Second Report of Session 2010-2011, Vol. 1, 2011. Available at 〈http://www.publications.parlia ment.uk/pa/cm201011/cmselect/cmenergy/450/450i.pdf

[23] UK Review Panel, Offshore Oil and Gas in the UK - An Independent Review of the Regulatory Regime, 2011. 〈https://www.gov.uk/government/uploads/sys tem/uploads/attachment_data/file/48252/3875-offshore-oil-gas-uk-ind-rev. $\mathrm{pdf}\rangle$.

\footnotetext{
${ }^{121}$ Interview with Mr. Jan de Jong, inspector-general of the State Mines, 22 February 2013.

122 Ibid.
} 